\title{
Role of Research and Development on Profitability: An Empirical Research on Textile Listed Firms in Vietnam
}

\author{
Manh Tien Pham ${ }^{1 *}$, Hai Duc Nguyen ${ }^{2}$, Quyen Tham Hoang ${ }^{3}$ \\ ${ }^{1}$ Faculty of Finance, Banking Academy of Vietnam, Hanoi, Vietnam. \\ e-mail: manhpham@hvnh.edu.vn \\ ${ }^{2}$ Microfinance Centre, Banking Academy of Vietnam, Hanoi, Vietnam. \\ ${ }^{3}$ DDP Student (DDP0202027), Institute of International Finance Education, Academy of Finance, Hanoi, \\ Vietnam.
}

DOI: 10.51865/EITC.2021.04.01

\begin{abstract}
The main purpose of this study is to determine the effect of R\&D spending on firm's profitability. The data was collected from listed firms in textile industry in Vietnam, from 2010-2020 period. The results show that, $R \& D$ spending, financial investment is positively and significantly influenced to ROA, ROE. However, financial leverage and firm size are negatively impact to firm's financial performance. In addition, there is no relationship between profitability and fixed assets, intangible asset of the company. The research also gives some implications for Vietnamese enterprises to increase their financial performance.
\end{abstract}

Keywords: $R \& D$; profitability; listed firms.

JEL Classification: F66; G23; G32.

\section{Introduction}

According to the PwC Global Innovation Survey (2013), more than $80 \%$ of businesses believe that innovation is critical to their long-term success, and nearly $90 \%$ expect that this will remain the case in the next five years. However, Vietnamese enterprises have not really focused on long-term development, almost not all businesses understand the importance of investing in research and development $(\mathrm{R} \& \mathrm{D})$ to have get a competitive advantage in the market $(\mathrm{OECD}$, 2021)

In the contemporary world, the topic related to the influence of R\&D on the firm's profits of has been one of the noticeable topics that have been studied and proven over the years. It is generally accepted that research and development $(\mathrm{R} \& \mathrm{D})$ use assumes a vital part in upgrading firm performance (O'Mahony and Vecchi, 2009; Sharma, 2012; Kim et al., 2018; Koutroumpis,

\footnotetext{
* Corresponding author
} 
2020). The achievement of enormous companies (like Samsung Electronics, Hyundai Motor, Huawei and Apple) has exhibited the significance of $R \& D$ in expanding profit and keeping up competitiveness. Griliches (1979) states that spending in R\&D will improve a company's load of knowledge, prompting better innovation, which can expand yield because of expanded productivity. By the by, there are likewise risks and expenses related with R\&D activities. Teece (1986) underscores that R\&D activities increment the firm's operating cost, so these exercises should be gone with great production and marketing processes. Kim and Cho (2014) express that R\&D carries more risk to organizations since the failure proportion of this activities is extremely high.

This research focuses on the influence of the following indicators: Research and development costs, fixed asset costs, intangible asset costs, financial investment costs, as well as financial leverage results to the after-tax profits of listed companies on the stock market and then make recommendations. Therefore, this research is going to examine the relationship between R\&D spending on financial firm's performance in listed companies in Vietnam, to contribute the literature in Vietnam research, and to help firms' manager pay more attention in this matter when they build their companies' strategies development.

\section{Literature Review}

Nguyen and Nguyen (2020) supposed that profitability is quite possibly the main elements to think about while assessing an organization's performance, since it shows the profit margin comparable to asset investment, equity, or sales. Profitability improvement is one of the imperative errands for organizations today, particularly with regards to Vietnam's international economic integration. Since just a steady economy with high profitability can give adequate financial resources to long-term development, it can draw in both domestic and international consideration and investment. Profitability isn't just a credible basis for dissecting business achievement, yet it is additionally a valuable instrument for anticipating future business performance. Profitability addresses the wealth of shareholders and, accordingly, appeals to investors. This is the reason discovering distinct components that influence profitability straightforwardly or indirectly to profitability is a fundamental exploration topic in economics, strategic management, accounting and finance.

The relationship between R\&D activities on firm productivity has been long paid attention to by various researchers global. Monte and Papagni (2003) examined the development of organizations under the impacts of innovative activities. Interestingly, findings from the research indicated that the impacts of R\&D activities on organization's growth were stronger in traditional sectors than that in sectors with high research intensity. This finding is proved to be beneficial for the managers in order to have deep insights into the impacts of R\&D activities in profitability which is the operational profit only instead of the gross one.

With focus into the impacts on the association between R\&D expenditures and profitability, Kiraci et al (2016) developed a conceptual framework in which independent variable of the research was R\&D expenditure and dependent variables are Net profit for the period, Operating profit, and Gross Real Operating Profit. It was revealed by the research's findings that while the impacts of R\&D expenditures on the short-term profitability are statistically insignificant, the long-term profitability is affected positively and strongly by the R\&D expenditures. Specifically, the gross profitability of the enterprise is affected the most by $R \& D$ expenditures following which if R\&D expenditures increase 1 unit, the gross profit will improve 10.19 units accordingly. The impact of R\&D on financial performance of those organizations has been shed light on in the 10-year period from 2007 to 2018 in which financial performance was measured by the ratio of return on assets (ROA) and the ratio of return on equity (ROE) as two major indicators while the $R \& D$ expenditure was measured by $R \& D$ intensity and $R \& D$ expenditure 
over total sales. Findings from the research have indicated an inverted-U shape nonlinear association between R\&D expenditure of the 62 Turkish organizations and their financial performance.

Johansson and Loof (2008) have conducted research in a large scale with 1,767 randomly selected enterprises in the manufacturing sector in Sweden. The results show that organization whose R\&D activities are conducted on frequent basis usually perform better than the ones with occasional or even no R\&D activities. In addition, the relationship between occasional $R \& D$ activities on lower performance is proved to be more significant than the no R\&D activities.

However, Onyekwere (2019) indicated a lower coefficient for R\&D expenditure indicating a small positive impact on productivity growth. Therefore, the research suggested that the contribution of $\mathrm{R} \& \mathrm{D}$ advancement into the productivity enhancement of organization was not exogenous but depending greatly on the R\&D decisions of firms. In addition, researcher also concluded that the R\&D investment could contribute to higher labor productivity in the field of manufacturing sector in the UK.

Along with numerous international research papers into the topic of R\&D expenditures and firm productivity, there are several studies conducted by Vietnamese researchers in the same topic with the focus on Vietnam market. Nguyen and Pham (2017) have made attempts to identify the impacts of $\mathrm{R} \& \mathrm{D}$ expenditures on the financial performance of Vietnam enterprises with the ROA as the major indicator of firm performance. Findings from the research have indicated that among the five independent variables, three of them (firm size, dividend payout ratio and R\&D spending) have statistically significant impacts on the financial performance of organization. The research examined enterprises from wide variety of different sectors instead of focusing on certain identified sector like other prior researches which might contribute to better generalization of the research results. Nevertheless, the firm size which divides organizations into large, small and medium enterprises was ignored in this paper which might be seen as a research gap which should be paid further attention to by other future researches.

Also focusing on the impacts of R\&D expenditures on the firm performance in the context of Vietnam, Quan and Le (2020) collected data from 343 listed organization in the Vietnam Stock Exchange, to find out the relationship between R\&D cost and firm output. Following which, 1\% improvement in the $\mathrm{R} \& \mathrm{D}$ expenditure in Vietnam will result in better output than $1 \%$ improvement in R\&D expenditure in other nations. Other factors such as fuel consumption, technology transfer and raw materials seem to be omitted which invite other researches to be conducted in the future.

According to Nguyen et al (2017), the relationship between innovation and firm performance in small and medium enterprises (SMEs) in Vietnam is proved to be significant. Findings from the research indicated that the R\&D spending could be beneficial for enterprises to innovate new products, create new production process and add values to the existing ones. Eventually, the financial performance of the organization would be improved accordingly.

Given the above empirical evidence, it is concluded that the attention to the impacts of $R \& D$ expenditure on the profitability and firm performance has long been paid attention to by various researches. Among those, some of the most typical papers are selected and analyzed in the previous section of this chapter which examined the impacts of R\&D expenditure on performance and output of organization at firm, region and country levels. Nevertheless, there are still some gaps in the literature following which the researcher is motivated to conduct further research into this topic, especially in Vietnam:

First of all, most previous researches focus on specific industries like pharmaceutical and manufacturing industries only. Some limited researches with focus on various industries, however, only pay attention to the impacts of $R \& D$ expenditure on the overall performance of 
organization excluding clear variables such as revenues, profits, ROA or ROE as the independent variables.

Secondly, given the case of Vietnam as an emerging market, attention to the impacts of R\&D expenditure on organization's performance is proved to be limited due to the data unavailability. There are, however, some micro-level researches to be conducted yet they mainly focus on the staff's productivity and performance rather than the financial performance of the organization.

Thirdly, some available researches in the context of Vietnam only collect data within short-time duration of less than 10 years only. Thus, this paper is expected to fulfill this research gap by providing a fresh look into the impacts of $R \& D$ expenditure on the profitability and firm performance of Vietnamese enterprise with the special focus on ROA and ROE as the two variables of the dependent variables - profitability of the enterprises.

\section{Data and Hypotheses}

This research is going to collect data from 21 enterprises operating under the textile industry group on the entire Vietnamese stock exchange, including the Ho Chi Minh City Stock Exchange (HOSE), Hanoi Stock Exchange (including HNX and UPCOM) in the period 2010 2020 , with a total of 205 research samples. The variables and description in this research are shown in the Table 1.

Table 1. Variables under the research

\begin{tabular}{|c|c|}
\hline Variables & Description \\
\hline \multicolumn{2}{|l|}{ Dependent variable } \\
\hline Firm performance (ROA) & Profit after tax/total asset \\
\hline Firm performance (ROE) & Profit after tax/total equity \\
\hline \multicolumn{2}{|l|}{ Independent variables } \\
\hline Research and Development Spending (RD) & Total R\&D spending/Total assets \\
\hline Intangible assets (IA) & Logarit of Intangible assets \\
\hline Fixed assets (FA) & Logarit of Fixed assets \\
\hline Financial Investment (FI) & Logarit of Financal investment \\
\hline Firm size (SIZE) & Logarit of Total Assets \\
\hline Financial Leverage (LEV) & Total Debt/Total Equity \\
\hline \multicolumn{2}{|l|}{ Control variables } \\
\hline GDP & Gross Domestic Product \\
\hline Inflation (INF) & Consumer price index \\
\hline
\end{tabular}

Source: Authors' calculation.

\section{Research Models}

In this research, we are going to follow the research of Kiraci et al (2016), with some modifies for Vietnam situations:

Model 1:

$$
\begin{aligned}
R O A_{i, t}=\beta_{0}+ & \beta_{1} R D_{i, t}+\beta_{2} I A_{i, t}+\beta_{3} F A_{i, t}+\beta_{4} F I_{i, t}+\beta_{5} S I Z E_{i, t}+\beta_{6} L E V_{i, t}+\beta_{7} G D P_{i, t} \\
& +\beta_{8} I N F_{i, t}+\varepsilon
\end{aligned}
$$

Model 2:

$$
\begin{aligned}
R O E_{i, t}=\beta_{0}+ & \beta_{1} R D_{i, t}+\beta_{2} I A_{i, t}+\beta_{3} F A_{i, t}+\beta_{4} F I_{i, t}+\beta_{5} S I Z E_{i, t}+\beta_{6} L E V_{i, t}+\beta_{7} G D P_{i, t} \\
& +\beta_{8} I N F_{i, t}+\varepsilon
\end{aligned}
$$

Where: firm (i); time period (t); correlation coefficients ( $\beta$ ); error ( $\varepsilon$ ); RS, FI, IFA, TFA, SIZE, LEV, GDP and INF are described in the Table 1. 


\section{Hypotheses}

To find out the relationship between independent and control variables with profitability, we are going to test the hypotheses below:

$\mathrm{H}_{1}$ : R\&D expenditure significantly impact on firm's profitability.

$\mathrm{H}_{2}$ : Intangible assets has significantly impact on firm's profitability.

$\mathrm{H}_{3}$ : Fix assets has significantly impact on firm's profitability.

$\mathrm{H}_{4}$ : Financial investment significantly impact on firm's profitability.

$\mathrm{H}_{5}$ : Firm size has significantly impact on firm's profitability.

$\mathrm{H}_{6}$ : Financial leverage has significantly impact on firm's profitability.

$\mathrm{H}_{7}$ : GDP has significantly impact on firm's profitability.

$\mathrm{H}_{8}$ : Inflation has significantly impact on firm's profitability.

\section{Empirical Results and Discussion}

Table 2 shows descriptive statistic of all variables. Based on the research results, the average ROA of companies in the textile industry is $5.2 \%$ with a standard deviation of $11.5 \%$. Along with that, the average ROE is $21.1 \%$ with the standard deviation up to $43.01 \%$ because there are businesses with the five highest ROE ratios up to 593\%. Moreover, between 2010 and 2020 firms invest more in fixed assets than in R\&D (5.04 vs. 3.03 respectively). In particular, there are some companies have negative spend amount on $\mathrm{R} \& \mathrm{D}(-1.02)$, this means the spending in excess of fund for $R \& D$, and the others spend a large amount of money on $R \& D(6.57$ at maximum).

Table 2. Descriptive statistic

\begin{tabular}{|l|l|l|l|l|l|}
\hline Variable & Obs & \multicolumn{1}{|c|}{ Mean } & \multicolumn{1}{|c|}{ Std. Dev. } & Min & Max \\
\hline ROE & 204 & 0.211 & 0.430 & $(0.663)$ & 5.937 \\
\hline ROA & 204 & 0.053 & 0.115 & $(0.830)$ & 0.453 \\
\hline R\&D & 191 & 3.031 & 1.934 & $(1.022)$ & 6.577 \\
\hline IA & 153 & 0.929 & 2.432 & $(4.605)$ & 5.561 \\
\hline FA & 205 & 5.049 & 1.845 & $(1.109)$ & 8.879 \\
\hline FI & 187 & 1.696 & 2.005 & $(4.605)$ & 6.990 \\
\hline SIZE & 205 & 2.860 & 0.685 & 1.066 & 4.340 \\
\hline LEV & 205 & 2.160 & 1.902 & $(3.750)$ & 11.870 \\
\hline GDP & 231 & 0.060 & 0.011 & 0.029 & 0.071 \\
\hline INF & 231 & 0.058 & 0.048 & 0.006 & 0.187 \\
\hline
\end{tabular}

Source: Research result.

Table 3 reports the correlation coefficients between variables under the research. Some of correlation coefficients are statistically significant variable pairs are: R\&D - FA (71.6\%\%), FA - IA (44.14\%), SIZE - R\&D (74.89\%), SIZE - FA (88.54\%), SIZE -FI (77.84\%). However, most of the numbers are lower than $80 \%$ so it does not have significant effect, except for FA and SIZE. It is clearly seen that, the bigger size of companies, the higher investing on fixed asset because the assets represent a part of the companies' position and size. Moreover, it is clear from the table 4 that, there is a positive statistically correlation between R\&D spending and Fixed asset, intangible asset, and firm size. This means that, companies with larger asset will spend more money on R\&D, and large firms have more R\&D spending. 
Table 3. The correlation matrix

\begin{tabular}{|l|l|l|l|l|l|l|l|l|l|l|}
\hline & ROA & ROE & R\&D & IA & FA & FI & SIZE & LEV & GDP & INF \\
\hline ROA & 1 & & & & & & & & & \\
\hline ROE & - & 1 & & & & & & & & \\
\hline R\&D & 0.1370 & 1 & & & & & & & & \\
\hline IA & - & -0.0714 & 1 & & & & & & & \\
\hline FA & 0.2118 & -0.1823 & 0.2593 & 1 & & & & & & \\
\hline FI & 0.0651 & -0.0143 & 0.5931 & 0.3204 & 0.6446 & 1 & & & & \\
\hline SIZE & 0.0929 & -0.0555 & 0.7489 & 0.3625 & 0.8854 & 0.7784 & 1 & & & \\
\hline LEV & 0.0543 & -0.2684 & -0.0088 & -0.0700 & 0.0482 & 0.1816 & 0.1506 & 1 & & \\
\hline GDP & 0.0001 & 0.0469 & -0.0552 & -0.0626 & -0.0510 & 0.0359 & -0.0540 & -0.0400 & 1 & \\
\hline INF & 0.1413 & 0.0356 & -0.1964 & 0.0651 & -0.0550 & 0.0495 & -0.0964 & 0.2139 & -0.0103 & 1 \\
\hline
\end{tabular}

Source: Research result.

Table 4. Results from OLS between variables with profitability

\begin{tabular}{|l|l|l|l|l|}
\hline \multirow{2}{*}{ Variables } & \multicolumn{2}{|c|}{ ROA } & \multicolumn{2}{c|}{ ROE } \\
\cline { 2 - 5 } & Coef. & P-value & Coef. & P-value \\
\hline RD & 0.009 & 0.004 & 0.026 & 0.005 \\
\hline IA & 0.001 & 0.702 & -0.008 & 0.127 \\
\hline FA & -0.011 & 0.082 & -0.026 & 0.172 \\
\hline FI & 0.005 & 0.122 & 0.023 & 0.017 \\
\hline SIZE & -0.062 & 0.002 & -0.139 & 0.016 \\
\hline LEV & -0.024 & 0.000 & -0.043 & 0.000 \\
\hline GDP & 0.602 & 0.071 & 1.961 & 0.043 \\
\hline INF & 0.242 & 0.008 & 0.783 & 0.003 \\
\hline Significant. F & 0.000 & 0.000 \\
\hline R-square & 0.537 & 0.394 \\
\hline
\end{tabular}

Source: Research result.

As can be seen from Table 4, the R-squared coefficient of ROA and ROE are 53.7\% and 39.4\% respectively showing that the independent variables explain $53.7 \%$ and $39.4 \%$, respectively of the variation of the independent variables, the rest is explained by out-of-model variables and random error.

With the random effect model, the $1 \%, 5 \%$, and $10 \%$ significance levels can be observed to see which prefixes are statistically significant on profitability. From the model's results, it can be seen that the variables IA and FA ( $p$-value $>10 \%$ ) are not statistically significant for ROA and ROE and GDP ( $\mathrm{p}$-value $=0.071$ of ROA and 0.043 of ROE are statistically significant at the $10 \%$ and $5 \%$ respectively level of significance. Variables RD, FI, SIZE, LEV and INF (p-value) are statistically significant at the $1 \%$ level of significance.

To identify the appropriate model, it is used Hausman test to choose between REM and FEM. The result of Hausman with ROA is Prob $>$ chi2 $=0,657$ and with ROE is Prob $>$ chi $2=0,324$. With the result numbers higher than 0,2 in both of ROA and ROE, REM is REM is an appropriate model chosen to use. 
Table 5. Results from REM between variables with profitability

\begin{tabular}{|l|l|l|l|l|}
\hline & \multicolumn{2}{|c|}{ ROA } & \multicolumn{2}{c|}{ ROE } \\
\hline & Coef. & P-values & Coef. & P-values \\
\hline SIZE & -0.062 & 0.002 & -0.142 & 0.013 \\
\hline LEV & -0.023 & 0.000 & -0.043 & 0.000 \\
\hline GDP & 0.533 & 0.099 & 1.762 & 0.059 \\
\hline INF & 0.273 & 0.003 & 0.835 & 0.002 \\
\hline RD & 0.009 & 0.004 & 0.026 & 0.004 \\
\hline IA & 0.001 & 0.649 & -0.008 & 0.125 \\
\hline FA & -0.011 & 0.079 & -0.025 & 0.177 \\
\hline FI & 0.005 & 0.123 & 0.024 & 0.013 \\
\hline Significant. F & 0.000 & 0.000 \\
\hline R-square & 0.536 & 0.392 \\
\hline
\end{tabular}

Source: Research result.

From Table 5, it is clear that, the R-squared coefficient of ROA and ROE are 53.6\% and $39.2 \%$ respectively showing that the independent variables explain respectively $53.6 \%$ and $39.2 \%$ of the variation of the independent variables, the rest is explained by out-of-model variables and random error.

With the random effect model, the $1 \%, 5 \%$, and $10 \%$ significance levels can be observed to see which prefixes are statistically significant on profitability. From the model's results, it can be seen that the variables IA and FA (p-value $>10 \%$ ) are not statistically significant for ROA and ROE and GDP (p-value $=0.099$ and 0.059 ) respectively by ROA and ROE are statistically significant at the $10 \%$ level of significance. Variables RD, FI, SIZE, LEV and INF (p-value) are statistically significant at the $1 \%$ level of significance.

As a result, the final research hypotheses are illustrated in the Table 6, with 5 hypotheses accepted and there are 3 rejection hypotheses.

Table 6. The summary of results from tests on Hypotheses

\begin{tabular}{|l|c|}
\hline \multicolumn{1}{|c|}{ Hypotheses } & Result \\
\hline $\mathrm{H}_{1}$ : R\&D expenditure has a significant impact on firm's profitability & Accept $\mathrm{H}_{1}$ \\
\hline $\mathrm{H}_{2}$ : Intangible assets has a significant impact on firm's profitability & Reject $\mathrm{H}_{2}$ \\
\hline $\mathrm{H}_{3}$ : Fix assets has a significant impact on firm's profitability & Reject $\mathrm{H}_{3}$ \\
\hline $\mathrm{H}_{4}$ : Financial investment has a significant impact on firm's profitability & Accept $\mathrm{H}_{4}$ \\
\hline H5: Firm size has a significant impact on firm's profitability & Accept H5 \\
\hline H6: Financial leverage has a significant impact on firm's profitability & Accept H6 \\
\hline H7: GDP has a significant impact on firm's profitability & Reject $\mathrm{H} 7$ \\
\hline H8: Inflation has a significant impact on firm's profitability & Accept H8 \\
\hline
\end{tabular}

Source: Research result.

\section{Conclusions}

The textile industry is a long-standing industry in Vietnam, businesses in the industry have also been listed on the stock exchange for a long time and are growing and attracting the attention of investors. Research and development is basically the first step to take to develop a new product line or a new feature for a product. Not only stopping at the newborn of a product, it refers to the entire life cycle of the product from commence to production, trading, innovation to production suspension. However, the development of Vietnam's textile and garment industry does not depend on the differentiation strategy but on the cost leadership strategy. In addition, most domestic textile enterprises are small and medium-sized, so research and development costs are mainly spent on product design and development, advertising and marketing, studying 
the market of demand. R\&D also represents the long-term vision of an enterprise and its future strategy when operational innovation is more in terms of an economic model of the business.

Based on the above research results, the study shows the impact between research and development and corporate profits, thereby, making the following recommendations:

First, research and development has positive impact on the profitability of the business. Since most of the garment enterprises in Vietnam are small and medium, they mainly use the cost leadership strategy. That is to take advantage of cheap labor and cheap input materials to have a price advantage. Therefore, the research and development costs of some enterprises are not used effectively leading to the results of the research paper. However, in order to improve its competitive position with other countries in the world, Vietnam should focus more on investment in research and development to diversify its business fields, as well as improve and improve the quality of products. products as well as create new products that attract more customers. With rapid changes in technology and techniques, especially in the time of Industry 4.0, businesses should choose reasonable areas for research and development to keep pace with market changes. Thus, Vietnam's garment industry will have the advantage of both price and product uniqueness. This will improve operational efficiency and increase profits. Enterprises should also allocate a reasonable proportion of expenses for research and development in business to bring profits. In addition, enterprises in Vietnam in general and those in the textile industry in particular should pay more attention to setting aside reasonable funds to invest in research and development. With rapid changes in technology and techniques, especially in the time of Industry 4.0, businesses should choose reasonable areas for research and development to keep pace with market changes.

Secondly, due to a negative relationship between firm's profit and leverage, businesses should businesses should use a reasonable leverage ratio. The results of the correlation model also show that financial leverage has a negative correlation with corporate profits in the textile industry. Because a lot of debt comes with a lot of interest costs, along with a high leverage ratio can expose a business to liquidity problems that can lead to negative profit and further bankruptcy

Thirdly, there is a positive relationship between firm's profit and financial investment. Based on the research results, the thesis recommends that businesses should invest in financial investments, loans, and joint venture capital contribution, thereby helping to increase the profit of the enterprise. However, companies better maintain a reasonable level of financial costs and avoid wasting money.

Fourthly, the size of the business has a negative impact on the profitability of the business. Based on the research results, the thesis has recommendations for businesses to outline clear strategies to develop and expand their businesses and focus on researching, improving and improving the efficiency and quality of products in the main areas with the most potential. After gaining a position and gaining the trust of consumers as well as investors, it is possible to consider expanding the scale of the business, avoiding scaling in many areas with no potential for development because of the ability to expand the business, high loss potential, expensive costs along with reducing the profit of the business.

Fifthly, investments of fixed assets, intangible assets have no impact on the profitability of the business. Based on the research results, the thesis recommends that businesses should not invest too much in fixed assets and intangible fixed assets to avoid causing waste without bringing any substantial profit.

At last, both of controllable factors as GDP and inflation have impact on firm's profit. It is said that, beside of internal factor mention above, there are other external factor that have significant influence in firm's performance. However, it is negative or positive stimulus due to firm's industry and position of each firm in the industry. 


\section{References}

1. Bouaziz, Z., 2016. The Impact of R\&D Expenses on Firm Performance: Empirical Witness from the BIST Technology Index. Journal of Business Theory and Practice, 4(1).

2. Erdogan, M. and Yamaltdinova, A., 2019. A Panel Study of the Impact of R\&D on Financial Performance: Evidence from an Emerging Market. Procedia Computer Science, 158, 541-545.

3. Ghaffar, A. and Khan, W. A., 2014. Impact of Research and Development on Firm Performance. International Journal of Accounting and Financial Reporting, 4(1), 357-367.

4. Griliches, Z., 1979. Issues in assessing the contribution of research and development to productivity growth. Bell Journal of Economics, 10, 92-116. https://doi.org/10.2307/300332

5. Johansson, B. and Loof, H., 2008. The Impact of Firm's R\&D Strategy on Profit and Productivity. CESIS Electronic Working Paper Series. The Royal Institute of Technology.

6. Kim, H., Kim, Y., and Cho, K., 2014. The effect of research and development investment and desorptive capacity on firm performance. Asian Journal of Technology Innovation, 22(2), 252-267. https://doi.org/10.1080/19761597.2014.973163

7. Kiraci, M., Celikay, F. and Celikey, D., 2016. The Effects of Firms' R\&D Expenditures on Profitability: An Analysis with Panel Error Correction Model for Turkey. International Journal of Business and Social Science, 7(5), 233-240.

8. Le, T. T. and Quan, M. Q. B., 2021. The impact of R\&D expenditure on firm performance in emerging markets: evidence from the Vietnamese listed companies. Asian Journal of Technology Innovation, 1, 1-20.

9. Monte, A. D. and Papagni, E., 2003. R\&D and the growth of firms: empirical analysis of a panel of Italian firms. Research Policy, 32, 1003-1014.

10. Nguyen, N. A., Pham, Q. N., Nguyen, D. C, and Nguyen, D. N., 2007. Innovation and Export of Vietnam's SME Sector. Development and Policies Research Center, MPRA Paper, 3256, 72-99.

11. Nguyen, T. N. L. and Nguyen, V. C., 2020. The Determinants of Profitability in Listed Enterprises: A Study from Vietnamese Stock Exchange. Journal of Asian Finance, Economics and Business, Vol 7 No 1, 47-58.

12. Nguyen, T. P. and Pham, T. M., 2017. The relationship between Research and development (R\&D) spending and Firm's financial performance: Case study of listed firms on Vietnam Stock Exchange. Imperial Journal of Interdisciplinary Research, 3(8), 7-13.

13. OECD, 2020. SME and Entrepreneurship Policy in Viet Nam. OECD studies on SMEs and Entrepreneurship, 11.

14. Onyekwere, S. C., 2019. The Impact of Research and Development (R\&D) Expenditure on Productivity Growth: A Panel Data Evidence from the UK Manufacturing Sector. Asian Journal of Economics and Empirical Research, 6(2), 2409-2622.

15. O'Mahony, M., and Vecchi, M., 2009. R\&D, knowledge spillovers and company productivity performance. Research Policy, 38(1), 35-44. https://doi.org/10.1016/j.respol.2008.09.003.

16. Quan, M. Q. B. and Le, T. T., 2020. The Effect of R\&D Expenditure on Firm Output: Empirical Evidence from Vietnam. Journal of Asian Finance Economics and Business, 7(6), 379-385.

17. Teece, D. J., 1986. Profting from Technological Innovation: Implications for Integration, Collaboration, Licensing and Public Policy. Research Policy, 15(6), 285-305. https://doi.org/10.1016/0048-7333(86)90027-2.

18. Shen, K., Yan, M. and Tzeng, G., 2017. Exploring R\&D Influences on Financial Performance for Business Sustainability Considering Dual Profitability Objectives. Sustainability, 9.

19. Soltanisehat, L., Alizadeh, R. and Mehregan, N., 2018. Research and Development Investment and Productivity Growth in Firms with Different Levels of Technology. Iranian Economic Review, 23(4), 795-818.

20. Vurur, N. S. and Ilarslan, K., 2016. Analysis of the Relationship between R\&D Expenditure and Profitability: A Sample Application from BIST. Journal of Multidisciplinary Developments, 1(1), 103-112.

21. Zhang, Z., Zhu, Q. and Mogorron-Guerrero, H., 2019. How Does R\&D Investment Affect the Financial Performance of Cultural and Creative Enterprises? The Moderating Effect of Actual Controller. Sustainability, 11. 